\title{
Analisis Kesulitan Belajar Mahasiswa pada Mata Kuliah Mekanika
}

\author{
Diah Nugraheni \\ Pendidikan IPA IKIP Veteran Jawa Tengah \\ e-mail: diah85heni@gmail.com
}

\begin{abstract}
Abstrak
Penelitian ini bertujuan untuk mengungkap hal-hal yang dianggap sebagai kesulitan belajar pada materi Mekanika. Penelitian ini merupakan penelitian deskriptif kualitatif yang berupaya untuk mendeskripsikan jenis-jenis kesulitan mahasiswa dalam menyelesaikan persoalan mekanika. Subjek dalam penelitian ini adalah mahasiswa semester tiga Pendidikan IPA IKIP Veteran Jawa Tengah yang mengambil mata kuliah Mekanika. Dalam penelitian ini, peneliti mengumpulkan informasi melalui tes diagnostik dan wawancara dengan mahasiswa. Instrumen yang digunakan dalam penelitian ini adalah tes diagnostik dan pedoman wawancara. Letak kesulitan belajar mahasiswa dilihat berdasarkan kesalahan yang dibuat dalam menyelesaikan tes diagnostik. Hasil analisis menunjukkan bahwa kesulitan belajar dalam mempelajari mekanika terletak pada kemampuan matematis dasar yaitu diferensial dan integral. Dengan demikian, pengajar perlu mengembangkan strategi pembelajaran sehingga kemampuan berpikir mahasiswa dalam memecahkan masalah semakin meningkat.
\end{abstract}

Keywords: kesulitan belajar, mekanika

\begin{abstract}
This study aims to reveal the things that are considered as learning difficulties in the subjects of Mechanics. This research belongs to qualitative descriptive research which attempts to describe students' learning difficulties analysis in Mechanics course. The subjects in this study are students of the third semesters of Science Education IKIP Veteran Central Java who take courses in Mechanics. In this study, researchers collect information through diagnostic tests and interviews with students. Instruments used in this study are diagnostic tests and interview guidelines. The location of student learning difficulties is seen based on student error in completing diagnostic test. The result of the analysis shows that learning difficulties in studying mechanics lies in the basic mathematical ability that is differential and integral. Thus, it is necessary for the lecturer of Mechanics course to develop learning strategies so that students thinking ability in solving the problem improved.
\end{abstract}

Keywords: difficulties of learning, mechanics 


\section{PENDAHULUAN}

Pendidikan merupakan kebutuhan bagi setiap orang. Merujuk pada pasal 1 ayat 1 Undang-undang No. 20 Tahun 2003 tentang Sistem Pendidikan Nasional (UUSPN) menyatakan bahwa "Pendidikan merupakan usaha sadar dan terencana untuk mewujudkan suasana belajar dan proses pembelajaran agar peserta didik secara aktif mengembangkan potensi dirinya untuk memiliki kekuatan spiritual keagamaan, pengendalian diri, kepribadian, kecerdasan, akhlak mulia, serta keterampilan yang diperlukan dirinya, masyarakat, bangsa, dan negara".

Pendidikan lebih ditekankan pada prosesnya. Proses pendidikan merupakan kegiatan yang dilakukan oleh pendidik secara terarah yang bertujuan untuk menentukan kualitas hasil pencapaian tujuan pendidikan. Yang menjadi tujuan utama pengelolaan proses pendidikan yaitu terjadinya proses belajar dan pengalaman belajar yang optimal (Umar \& La Sulo, 2012). Dalam pelaksanaannya, mahasiswa dituntut untuk menguasai materi yang diberikan selama pelaksanaan pembelajaran. Indikator keberhasilan mahasiswa dalam menguasai materi yang diberikan yaitu adanya peningkatan kualitas hasil belajar mahasiswa di perguruan tinggi.

Mahasiswa masih mengalami kesulitan belajar dalam menguasai materi yang diberikan oleh dosen. Kesulitan belajar merupakan terjemahan dari Bahasa Inggris "Learning Disability" yang berarti ketidakmampuan belajar. Kata disability diterjemahkan "kesulitan" untuk memberikan kesan optimis bahwa seseorang sebenarnya masih mampu belajar (Suryani, 2010). Hal yang juga dapat menjadi ukuran untuk mengetahui penyebab kesulitan belajar mahasiswa adalah hambatan-hambatan yang dialami mahasiswa dalam proses pembelajaran (Faika \& Side, 2011).

Menurut Ismail (2016), kesulitan belajar dapat diartikan sebagai suatu kondisi dalam proses belajar yang ditandai adanya hambatan-hambatan tertentu untuk mencapai hasil belajar. Kesulitan ini sering tampak sebagai kesulitan belajar yang disebabkan oleh tidak dikuasainya keterampilan prasyarat, yaitu keterampilan yang harus dikuasai terlebih dahulu sebelum menguasai keterampilan berikutnya (Ristiyani \& Bahriah, 2016).

Partowisastro (1986) mengemukakan bahwa "suatu masalah atau kesulitan belajar itu ada, kalau seorang mahasiswa itu jelas tidak memenuhi harapan-harapan yang diisyaratkan oleh perguruan tinggi. Salah satu harapan tersebut adalah tercapainya hasil belajar mahasiswa yang optimal.

Belajar merupakan proses penting bagi perubahan perilaku manusia dan mencakup segala sesuatu yang dipikirkan dan dikerjakan (Anni, C.T., dkk: 2005). Perubahan perilaku tersebut dituangkan sebagai hasil belajar yang diperoleh setelah mengalami aktivitas belajar. Perubahan perilaku tergantung pada apa yang dipelajari oleh seseorang. Apabila 
seseorang mempelajari pengetahuan tentang konsep, maka perubahan perilaku yang diperoleh adalah berupa penguasaan dan pemahaman konsep.

Mekanika (Mechanics) merupakan ilmu pengetahuan yang mempelajari gerak suatu benda serta efek gaya dalam gerak itu sehingga mahasiswa dituntut untuk menguasai konsep materi tersebut. Mekanika merupakan mata kuliah wajib yang ditempuh oleh mahasiswa Program Studi Pendidikan IPA di IKIP Veteran Jawa Tengah. Secara khusus, mata kuliah mekanika memerlukan materi dasar sebagai prasyarat. Prasyarat mata kuliah mekanika adalah matematika dasar dan fisika dasar. Oleh karena itu, materi ini harus mendapatkan perhatian yang cukup serius menyangkut masalah penguasaan materi, pemilihan metode pembelajaran yang tepat, penentuan strategi, dan teknik pembelajaran yang serasi sebagai bekal para mahasiswa pada perkuliahan selanjutnya. Hal ini sesuai dengan yang dikemukakan oleh Marsita, dkk (2010), bahwa konsep-konsep yang merupakan prasyarat untuk mempelajari konsep-konsep selanjutnya sangat penting untuk dikuasai dan dipahami.

Pengalaman dan fakta selama perkuliahan, masih ditemukan adanya kesalahankesalahan yang dilakukan mahasiswa dalam menyelesaikan soal-soal mata kuliah mekanika yang berakibat pada rendahnya hasil belajar. Beberapa sebab rendahnya hasil belajar mekanika adalah sebagai berikut: (1) Mahasiswa kurang menguasai materi prasyarat mekanika yang pernah dipelajari sebelumnya; (2) Mahasiswa kurang menguasai dan memahami konsep-konsep mekanika secara mantap; (3) Mahasiswa kurang mampu belajar mandiri, masih menggunakan metode hafalan; (4) Mahasiswa kurang cermat dan teliti dalam mengerjakan soal. Banyaknya kesalahan yang dilakukan mahasiswa dalam mengerjakan soal bisa menjadi petunjuk sejauh mana penguasaan mereka terhadap materi-materi yang ada. Dari kesalahan yang dilakukan, dapat diteliti dan dikaji lebih lanjut mengenai sumber kesalahan mahasiswa dan upaya pemecahannya. Berdasarkan uraian tersebut, perlunya penggalian informasi tentang faktor-faktor yang menyebabkan kesulitan mahasiswa IPA dan mengetahui letak kesalahan yang dilakukan mahasiswa IPA di IKIP Veteran Jawa Tengah dalam menyelesaikan soal-soal mekanika.

\section{METODE PENELITIAN}

Penelitian ini merupakan penelitian deskriptif kualitatif yang berupaya untuk mendeskripsikan kesulitan belajar mahasiswa sesuai dengan tujuan penelitian. Subyek dalam penelitian ini adalah 9 mahasiswa semester tiga Program Studi Pendidikan IPA IKIP Veteran Jawa Tengah tahun akademik 2016/2017 yang telah menempuh mata kuliah mekanika dan mengalami kesulitan belajar. Subjek tersebut telah mempelajari materi fisika dasar dan matematika dasar pada semester sebelumnya. 
Fokus penelitian ini adalah analisis kesulitan belajar mahasiswa dalam memahami konsep mekanika. Kesulitan belajar diukur dari penguasaan materi dan kesulitan dalam mengerjakan soal-soal tes yang diberikan. Untuk mengetahui kesulitan belajar mahasiswa digunakan instrumen penelitian berupa soal tes diagnostik dan wawancara. Soal tes diagnostik terdiri dari 5 soal yang mencakup gerak pada partikel, gaya konservatif, tumbukan, energi pada pegas, dan sistem banyak partikel. Soal tes juga dibuat sedemikian rupa untuk menemukan kekeliruan-kekeliruan atau kesalahan konsep, dan kesalahan proses yang terjadi pada mahasiswa ketika mempelajari mekanika, sehingga peneliti akan mengetahui hasil analisis mengenai letak dan jenis kesulitannya berdasarkan hasil pengerjaan tes. Selain dengan menggunakan tes tertulis, instrumen penelitian yang digunakan juga berupa wawancara secara tertulis untuk mengkonfirmasi jenis kesulitan yang dialami mahasiswa tersebut. Wawancara ini berfungsi untuk melengkapi dan memperkuat data hasil dari tes tertulis, serta mengungkapkan hal-hal yang tidak terungkap dalam tes tertulis. Dengan demikian, diperoleh gambaran mengenai kesulitan belajar yang dialami oleh mahasiswa.

Teknik analisis data yang digunakan adalah deskriptif naratif dengan menggunakan model Miles dan Huberman. Miles dan Huberman (dalam Sugiyono, 2011), mengemukakan bahwa aktivitas dalam analisis data kualitatif dilakukan secara interaktif dan berlangsung secara terus menerus sampai tuntas, sehingga datanya jenuh. Analisis data yang digunakan dalam penelitian ini terdiri dari empat bagian penting, yaitu pengumpulan data, reduksi data, penyajian data, dan kesimpulan hasil penelitian.

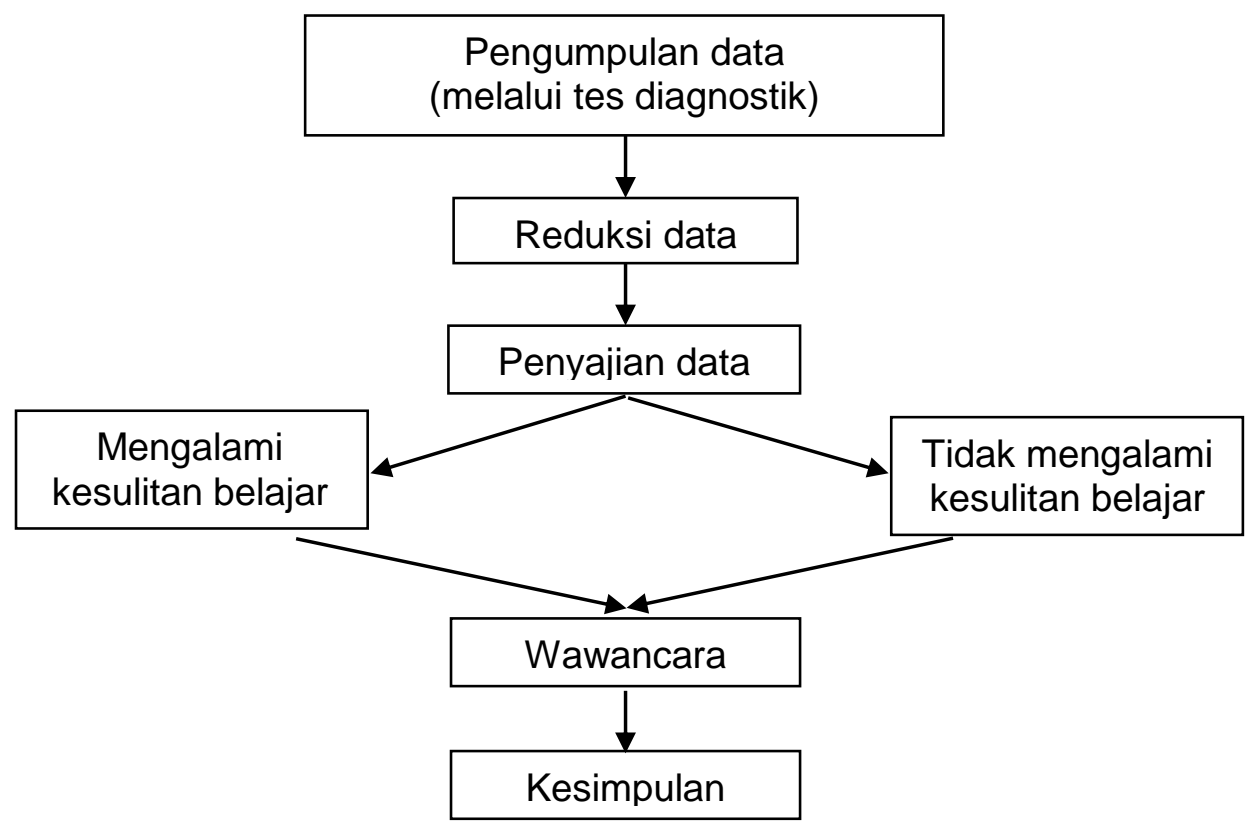

Gambar 1. Model Analisis Data menurut Miles dan Huberman 


\section{HASIL PENELITIAN DAN PEMBAHASAN}

Dalam penelitian ini, peneliti mengumpulkan informasi baik melalui tes diagnostik maupun wawancara pada mahasiswa. Berdasarkan hasil jawaban soal tes, peneliti memperoleh data-data yang dapat menunjukkan mahasiswa yang mengalami kesulitan belajar. Prosentase kesulitan belajar yang dialami mahasiswa pada tiap sub materi dapat dilihat pada tabel 1.

Tabel 1. Prosentase Kesulitan Belajar pada Setiap Sub Materi

\begin{tabular}{clcc}
\hline \multirow{2}{*}{ No. soal } & \multicolumn{1}{c}{ Sub Materi } & \multicolumn{2}{c}{ Kategori (dalam \%) } \\
\cline { 3 - 4 } & & $\begin{array}{c}\text { Mengalami kesulitan } \\
\text { belajar }\end{array}$ & $\begin{array}{c}\text { Tidak mengalami } \\
\text { kesulitan belajar }\end{array}$ \\
\hline 1. & Gerak pada partikel & 100 & 0 \\
2. & Gaya konservatif & 77,78 & 22,22 \\
3. & Tumbukan & 11,11 & 88,89 \\
4. & Energi pada pegas & 33,33 & 66,67 \\
5. & Sistem banyak partikel & 88,89 & 11,11 \\
\hline & Rata-rata & 62,22 & 37,78 \\
\hline
\end{tabular}

Hasil tes diagnostik terhadap materi mekanika diketahui bahwa kesulitan belajar tertinggi terdapat pada materi gerak pada partikel dengan prosentase 100\%. Secara keseluruhan, rata-rata prosentase kesulitan belajar pada mata kuliah mekanika adalah $62,22 \%$.

\section{Analisis Dokumen Hasil Tes Diagnostik}

1. Pada materi tentang gerak partikel, kesalahan yang dilakukan mahasiswa dalam menentukan jarak sebuah partikel apabila gaya gesek terhadap udara diketahui diantaranya: a) belum memahami konsep dalam perhitungan menggunakan differensial dan integral; b) mengetahui nilai persamaan jarak sebuah partikel tetapi belum memahami prosesnya; dan c) belum memiliki kemampuan matematis yang baik.

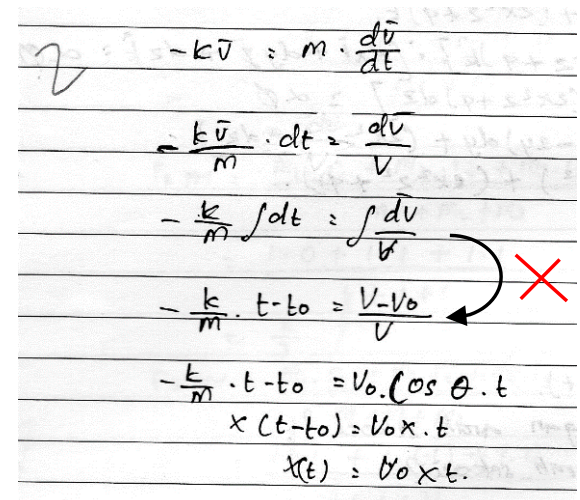

Gambar 2. Menentukan jarak sebuah partikel 
2. Pada materi gaya konservatif, kesalahan yang dilakukan mahasiswa adalah tidak menuliskan persamaan yang akan digunakan sebagai syarat untuk membuktikan bahwa gaya tersebut dikatakan konservatif (soal 2.a). Walaupun mahasiswa tidak menuliskan syaratnya, namun mereka mampu membuktikan dengan benar apa yang diminta dalam soal. Jadi, bisa dikatakan para mahasiswa masih menggunakan metode hafalan dalam mengerjakan soal.

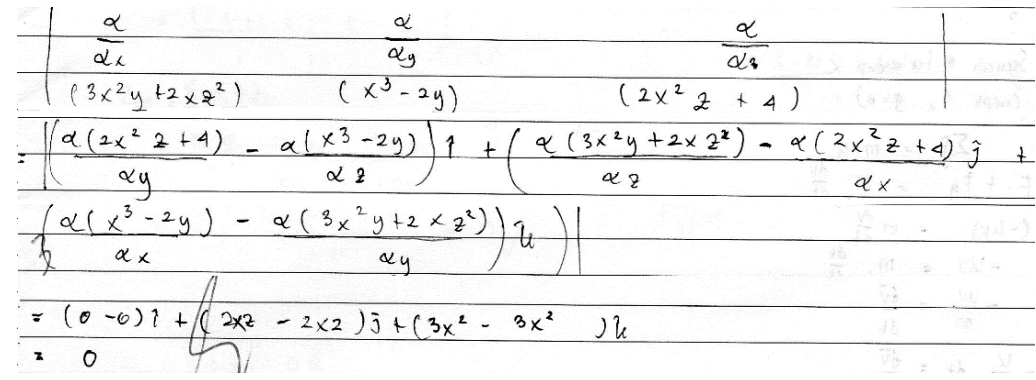

Gambar 3. Membuktikan gaya konservatif

Ketika pembahasan materi gaya konservatif, mahasiswa juga diminta menentukan nilai $\phi$ jika $F=\bar{\nabla} \phi$ (soal 2.b). Kesalahan yang dilakukan mahasiswa diantaranya: a) kesalahan perhitungan dan b) kurang menguasai konsep tentang penggunaan integral.

$\frac{2 b\left[\left(3 x^{2} y+2 x z^{2}\right) \hat{\imath}+\left(x^{3}-2 y\right) \hat{\jmath}+\left(2 x^{2} z+4\right) \hat{k}\right] \cdot[d x]}{\left(\left(3 x^{2} y+2 x z^{2}\right) d x+\left(x^{3}-2 y\right) d y+\left(2 x^{2} z+4\right) d z\right]=\partial \phi}$
$\left.2 \int \partial \theta=\int\left(3 x^{2} y+2 x z^{2}\right) d x+\left(x^{3}-2 y\right) d y+\left(2 x^{2} z+4\right) d z\right]$
$0=\left(x^{3} y+x^{2} z^{2}\right)+\left(x^{3}-y^{2}\right)+\left(1 / 2 x^{3} z^{2}+4\right)$

Gambar 4. Menentukan nilai $\phi$ jika $F=\bar{\nabla} \phi$

3. Pada materi tumbukan, mahasiswa diminta menentukan kecepatan akhir suatu benda apabila mengalami tumbukan. Kemampuan yang dimiliki mahasiswa pada soal ini diantaranya: a) memahami konsep tumbukan dengan baik; b) mampu menganalisis jenis-jenis tumbukan; dan c) memiliki kemampuan berhitung yang baik.

$\begin{aligned} m p \cdot v_{p}+m_{0} \cdot v_{0} & =m_{p} \cdot v p^{\prime}+m_{0} \cdot v_{0}{ }^{\prime} \\ 200 \cdot 2+50 \cdot 2 & =200 \cdot v_{p^{\prime}}+50 \cdot(-6) \\ 400+100 & =200 v p^{\prime}+(-300) \\ 500 & =200 v p^{\prime}+(-300) \\ -200 V p^{\prime} & =-300-500 \\ -200 v_{p} & =-800 \\ V p^{+} & =-800 \\ V p^{\prime} & =4 \mathrm{~m} / \mathrm{s} . \quad \mathrm{ll}\end{aligned}$

Gambar 5. Menentukan kecepatan akhir tumbukan 


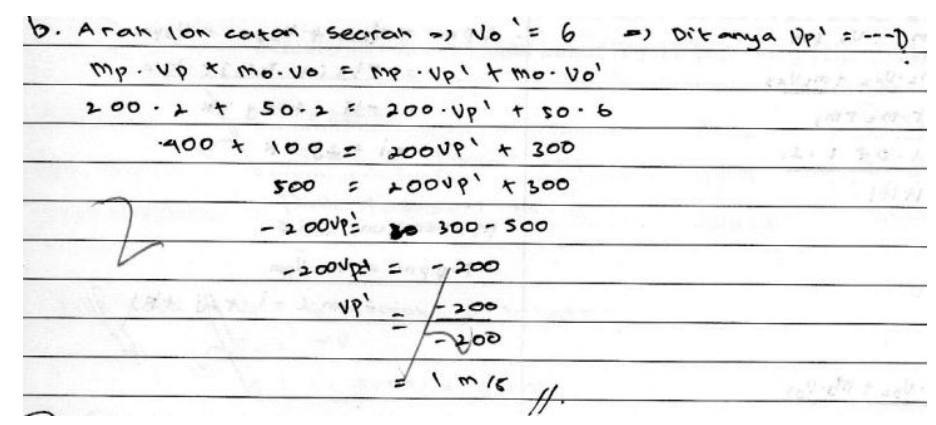

Gambar 6. Menentukan kecepatan akhir tumbukan

4. Pada materi energi pada pegas, mahasiswa diminta membuktikan persamaan energi potensial pegas apabila diketahui gaya pemulihnya. Kesalahan yang dilakukan mahasiswa adalah tidak menyertakan tanda (-) dalam proses pembuktikan sehingga tidak sesuai dengan yang dimaksud dalam soal.

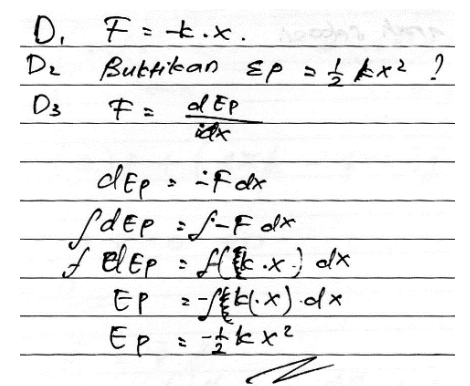

Gambar 7. Membuktikan persamaan energi potensial pegas

5. Pada materi sistem banyak partikel, mahasiswa diminta menghitung jarak dan kecepatan pusat massa. Kesalahan yang dilakukan mahasiswa diantaranya: a) kesalahan dalam memasukkan data; b) kesalahan dalam memahami maksud dari soal; c) tidak melakukan perhitungan terhadap posisi dan kecepatan pusat massa dari ketiga buah partikel; dan d) tidak menyertakan vektor satuan.

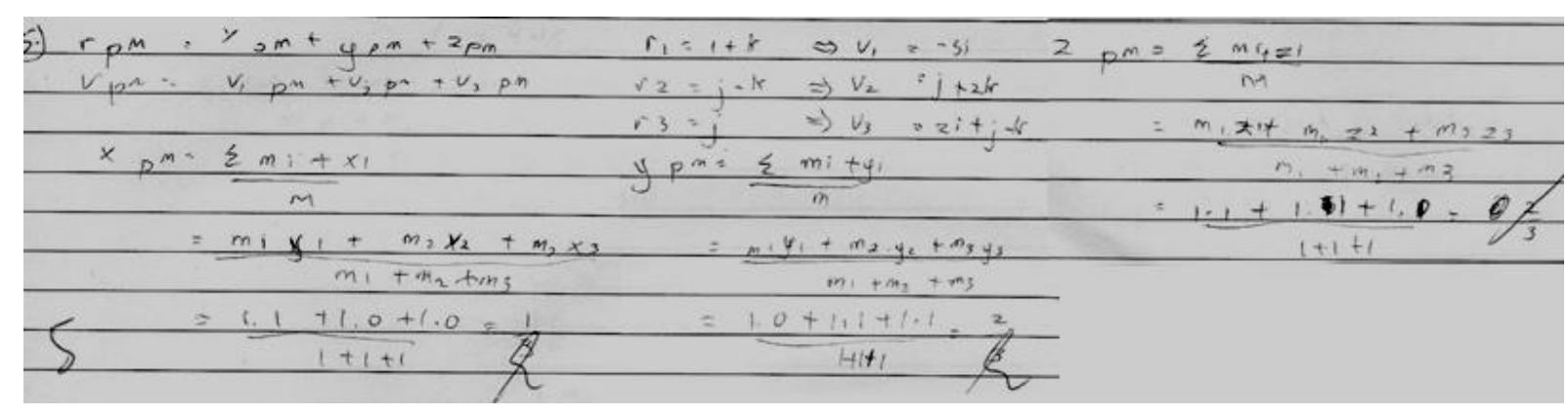

Gambar 8. Menghitung jarak dan kecepatan pusat massa 
Analisis dokumen hasil tes diagnostik di atas, terlihat bahwa matematika memang sangat dibutuhkan dalam menyelesaikan persoalan-persoalan dalam fisika. Sugeng (2014) berpendapat bahwa pelajaran fisika berhubungan langsung dengan matematika, dimana setiap permasalahan dalam fisika dapat diselesaikan dengan cara matematis. Menurut Haryadi \& Pujiastuti (2015), untuk memperdalam pemahaman konsep kinematika dibutuhkan keterampilan matematis guna mencari besaran-besaran fisisnya yaitu dengan differensial dan integral. Hal ini terlihat dari beberapa soal yang mengharuskan siswa memahami matematika dasar tentang konsep differensial dan integral untuk menyelesaikan soal-soal mekanika. Hal ini sesuai dengan pendapat Kereh, Subandar, \& Tjiang (2013) bahwa kesulitan belajar matematika dapat terjadi pada hampir setiap tahap/jenjang selama masa sekolah peserta didik, bahkan pada orang dewasa (mahasiswa).

\section{Analisis Dokumen Hasil Wawancara}

Hasil wawancara, diperoleh data bahwa pada prinsipnya mahasiswa memahami konsep-konsep dalam mekanika, akan tetapi ketika mengerjakan soal tersebut mengalami kebingungan dalam menentukan rumus atau cara untuk menyelesaikan soal, walaupun pada saat dosen menjelaskan materi, mereka sudah memahaminya. Berikut beberapa faktor yang menyebabkan mahasiswa mengalami kesulitan dalam menyelesaikan soalsoal mekanika berdasarkan hasil wawancara yang telah dirangkum, yaitu:

1. Pada materi gerak partikel, mahasiswa tidak menguasai dan memahami konsep-konsep sebelumnya yaitu tentang aturan differensial dan integral yang digunakan dalam menyelesaikan soal-soal tentang gerak suatu partikel.

2. Pada materi gaya konservatif, mahasiswa bisa mengerjakan soal pembuktian gaya konservatif (soal 2a) dengan benar karena sudah hafal dengan caranya. Namun, ketika mengerjakan soal $2 \mathrm{~b}$ untuk menentukan nilai $\phi$, mahasiswa kurang menguasai konsep tentang penggunaan integral sehingga menyebabkan kesalahan dalam perhitungan.

3. Pada materi tumbukan, mahasiswa sudah memahami konsep dan kemampuan berhitung yang baik sehingga soal mampu diselesaikan dengan benar.

4. Pada materi energi pada pegas, mahasiswa mengalami kebingungan untuk memasukkan tanda negatif (-) pengerjaan soal sehingga berpengaruh pada hasil akhir pembuktian energi potensial pada pegas.

5. Pada materi sistem banyak partikel, mahasiswa kurang teliti dalam membaca dan memahami soal sehingga jarak dan kecepatan pusat massa belum dikerjakan.

Hasil wawancara yang telah dilaksanakan selama pelaksanaan pembelajaran didapatkan data tentang faktor penting yang menyebabkan mahasiswa melakukan 
kesalahan adalah kurangnya latihan dalam mengerjakan soal yang berhubungan dengan differensial dan integral terutama pada kemampuan penguasaan keterampilan dalam menyelesaikan soal. Hasil yang diperoleh merupakan penjabaran dari data nilai yang diperoleh dan dipadukan dengan hasil wawancara terhadap subjek penelitian. Tidak menutup kemungkinan masih ada faktor lain yang menyebabkan mahasiswa mengalami kesulitan dalam menyelesaikan soal-soal mekanika, yang tidak terungkap baik dari hasil tes maupun dari hasil wawancara.

\section{SIMPULAN}

Berdasarkan hasil penelitian dan pembahasan dapat disimpulkan bahwa kesulitan belajar yang dialami mahasiswa adalah ada pada kemampuan matematis yang dimiliki mahasiswa dalam menyelesaikan soal mekanika, terutama yang berhubungan dengan differensial dan integral. Kesulitan yang dialami mahasiswa terletak pada kesalahan dalam memahami soal, kesalahan dalam keterampilan proses, dan kesalahan karena kurang cermat. Hasil penelitian ini kemudian akan dijadikan bahan pengembangan strategi pembelajarannya agar mahasiswa dapat lebih terasah kemampuan berpikirnya dan pengajar agar dapat memberikan latihan-latihan soal yang bervariasi kepada mahasiswa secara kontinu terutama yang berkaitan dengan mekanika.

\section{DAFTAR PUSTAKA}

Anni, C., T. 2004. Psikologi belajar. Semarang: Unnes Press.

Budiyono. 2003. Metodologi penelitian pendidikan. Surakarta: Sebelas Maret University Press.

Budiyono. 2004. Statistika untuk penelitian. Surakarta: Sebelas Maret University Press.

Faika, S., \& Side, S. 2011. Analisis kesulitan mahasiswa dalam perkuliahan dan praktikum kimia dasar di jurusan kimia FMIPA Universitas Negeri Makassar. Jurnal Chemica, 12(2): 18-26.

Haryadi, R., \& Pujiastuti, H. 2015. Pengaruh kemampuan matematis terhadap hasil belajar fisika. Prosiding Seminar Kontribusi Fisika (174-177). Institut Teknologi Bandung.

Ismail. (2016). Diagnosis kesulitan belajar siswa dalam pembelajaran aktif di sekolah. Jurnal Edukasi, 2(1): 30-43.

Kereh, C.T., Sabadar, J., \& Tjiang, P.C. 2013. Identifikasi kesulitan belajar mahasiswa dalam konten matematika pada materi pendahuluan fisika inti. Proceedings of Seminar Nasional Sains dan Pendidikan Sains VIII, Fakultas Sains dan Matematika, UKSW Salatiga. 
Marsita, R.A., Priatmoko, S., \& Kusuma, E. 2013. Analisis kesulitan belajar kimia siswa SMA dalam memahami materi larutan penyangga dengan menggunakan two-tier multiple choice diagnostic instrument. Jurnal Inovasi Pendidikan Kimia, 4(1): 512520.

Partowisastro, K. (1986). Diagnosa dan pemecahan kesulitan belajar 1. Jakarta: Erlangga.

Ristiyani, E., \& Bahriah, E. S. 2016. Analisis kesulitan belajar kimia siswa di SMAN X Kota Tangerang Selatan. Jurnal Penelitian dan Pembelajaran IPA (JPPI), 2(1): 18-29.

Sugeng. 2014. Korelasi kemampuan matematika dan fisika terhadap prestasi belajar mahasiswa teknik elektro D3 UNISMA. JREC (Journal of Electrical and Electronics), 2(1).

Sugiyono. 2011. Metode penelitian kuantitatif, kualitatif, dan R\&D. Bandung: Alfabeta.

Sukardi. 2003. Metodologi penelitian pendidikan (kompetensi dan praktiknya). Jakarta: Bumi Aksara.

Suryani, Y.E. 2010. Kesulitan belajar. Magistra, No. 73 Th. XXII.

Umar, T., \& La Sulo, S., L. 2012. Pengantar pendidikan. Jakarta: Rineka Cipta.

Undang-Undang No. 20 Tahun 2003 tentang Sistem Pendidikan Nasional (UUSPN).

Yulia, R. 2012. Analisis kesalahan mahasiswa matematika dalam menyelesaikan soal-soal logika. Jurnal Phenomenon, 2(1): 75-93. 